\title{
EFFECTS OF THE USE OF D-LIMONENE AS AN ADDITIVE TO DIESEL-BIODIESEL BLENDS ON EXHAUST GASES COMPOSITION OF COMPRESSION IGNITION ENGINES
}

\author{
L. F. Micheli, \\ D. L. Módolo, \\ and L. E. R. Pereira \\ Universidade Estadual Paulista (UNESP) \\ Faculdade de Engenharia, Bauru \\ Av. Eng. Luiz Edmundo C. Coube 14-01 \\ Bairro Vargem Limpa \\ 17033-360 - Bauru - SP \\ luis.micheli@unesp.br \\ delson.modolo@unesp.br \\ luiz.eduardo@unesp.br \\ Received: June 14, 2018 \\ Revised: July 19, 2018 \\ ABSTRACT \\ The transesterification of vegetable oils results in methyl esters of fatty acid, \\ known as biodiesel. This one presents similar features of diesel oil, such as \\ cetane number, specific weight, heat of combustion and air-fuel ratio. \\ However, arising problems from its higher viscosity leads to a poor \\ spraying by the fuel injectors and so to a low-grade combustion, causing \\ formation of undesirable deposits inside the engine, changes in the \\ properties of the lubricating oil and in the composition of the exhaust gas. \\ Owing to this issue, it is necessary to study an additive able to make \\ biodiesel characteristics more appropriate to be used in compression \\ ignition engines, as well as a monitoring of changes in exhaust gas \\ composition. The chosen additive was d-limonene, a monocyclic terpene \\ obtained as a byproduct of citriculture. This paper presents the preliminary \\ results obtained from the tests in a stationary diesel engine fuelled with \\ mixtures of diesel-biodiesel and d-limonene, in different concentrations, \\ comparing to regular diesel fuel. Although it was used in low \\ concentrations, the additive was efficient in the reduction of hydrocarbons, \\ carbon monoxide and opacity. \\ Accepted: Octorber 26, 2018 \\ Keywords: biodiesel; additive; D-Limonene; exhaust gases
}

\section{NOMENCLATURE}

$\mathrm{CO}$ carbon monoxide

$\mathrm{CO}_{2}$ carbon dioxide

$\mathrm{HC}$ hydrocarbons

K smoke density factor

L1 blend of commercial diesel oil plus $1 \%$ of D-

Limonene

L3 blend of commercial diesel oil plus 3\% of DLimonene

$\mathrm{NO}_{\mathrm{x}}$ nitrogen oxides

$\mathrm{NO}_{2}$ nitrogen dioxide

$\mathrm{O}_{2} \quad$ oxygen

ppm parts per million

S10 commercial diesel oil composed of $7 \%$ of biodiesel

\section{INTRODUCTION}

The concept of using vegetable oils, animal fats and even waste cooking oil as renewable diesel fuel is increasingly applicable to our world energy reality and is justified not only by the depletion of the world's oil reserves but also as a renewable and less aggressive alternative to the planet's environment and climate.

The direct use of vegetable oils in compression ignition engines despite being possible is not the best alternative due to the difference of properties such as kinematic viscosity, density and heat of combustion (Agarwal and Das, 2001; Clark et al., 1984; Costa Neto et al., 2000; Hunk and Barsic, 1981; Knothe et al., 2006).

However, when subjected to the transesterification process these properties become much closer to those of mineral diesel oil, but still exhibit high kinematic viscosity that results in a poor spray by the nozzles and consequently a lower grade combustion, leading to the formation of deposits inside the engine, lubricating oil contamination and changes in the exhaust gases composition (Gaurav et al., 2014; Gumus, 2010; Lapuerta et al., 2008; Xue et al., 2008).

In view of these characteristics, it is necessary to use additives in biodiesel in order to make the biodiesel characteristics even closer to mineral diesel, minimizing or eliminating the problems arising from its use.

The chosen additive was d-limonene, a natural, volatile and flammable organic compound (Breitmaier, 2006) obtained from orange peel in the orange juice production industries, which makes it a renewable resource as well (Corazza et al., 2011).

\section{EXPERIMENTS}

The tests were carried out at São Paulo State University (UNESP), School of Engineering, Bauru, in the Engine and Biofuels Laboratory.

The diesel oil used in the tests was acquired at a fuel station belonging to the BR distribution network and according to Brazilian legislation contains 10 ppm of sulfur, in this way, it will be referenced in this work as $\mathrm{S} 10$. 
It is important to emphasize that the commercialized diesel oil in Brazil contains 7\% of biodiesel in volume, regulated by law.

D-limonene, used as an additive in this project, was purchased from a company that operates in the orange juice manufacturing sector.

With this, two blends were prepared. One containing $1 \%$ of additive and another containing $3 \%$. Diesel without additive was also tested, named S10.

A stationary diesel generator set of the Branco brand, model BD-4000-CFE was used for the tests. The engine is air-cooled, a single cylinder direct fuel injection and $7.0 \mathrm{cv}(5.12 \mathrm{~kW})$ power rated, volumetric displacement of $0.296 \mathrm{~L}$ lubrication by oil pump.

At the output of the generator was connected an electrical system designed to simulate the real operating condition of the assembly, consisting of a bench containing 10 halogen lamps of 500W each, capable of dissipating a total power of $5 \mathrm{~kW}$. The assays were performed varying the load dissipated by the lamp assembly in the conditions of $500 \mathrm{~W}$, $1000 \mathrm{~W}, 1500 \mathrm{~W}, 2000 \mathrm{~W}, 2500 \mathrm{~W}$ and $3000 \mathrm{~W}$, keeping the engine rotation constant at $3600 \mathrm{rpm}$.

The exhaust gas measurements was performed by a gas analyzer of the brand TECNOMOTOR, model TM 131 equipped with NOx detection cell, and the data was collected by the software SOFTGAS provided by the equipment manufacturer who also provided an Opacimeter model TM 133 to measure the smoke opacity (particulate matter) and the software IGOR for its operation. This measurement is performed by the method of light absorption of a partial flow of the exhaust gases, captured by a probe in the exhaust pipe that takes the gases to the measurement chamber.

The exhaust gases temperature was measured through a type $\mathrm{K}$ thermocouple installed in the exhaust pipe close to the cylinder head where the exhaust valve is located, and its value was read in an automotive multimeter made by Instrutherm.

Finally, to measure the specific consumption, a Mariotte bottle (as a fuel tank) was placed in a bench scale with capacity of $10 \mathrm{~kg}$ and resolution of $1 \mathrm{~g}$, of the brand DIGI-TRON. This way it was possible to calculate the fuel flow, and then, the specific consumption.

\section{RESULTS AND DISCUSSION}

The results are presented as graphs, all based on the load imposed on the generator in Watts.

Figure 1 shows the data obtained for unburned $\mathrm{HC}$ emissions for different loading conditions. It can be observed that unburned $\mathrm{HC}$ emissions were significantly lower up to $2000 \mathrm{~W}$ of load, and after this value, the emissions of the two blends and the diesel without additives became closer, but the mixture containing $1 \%$ still presents lower emissions of unburned $\mathrm{HC}$ up to the load of $3000 \mathrm{~W}$.

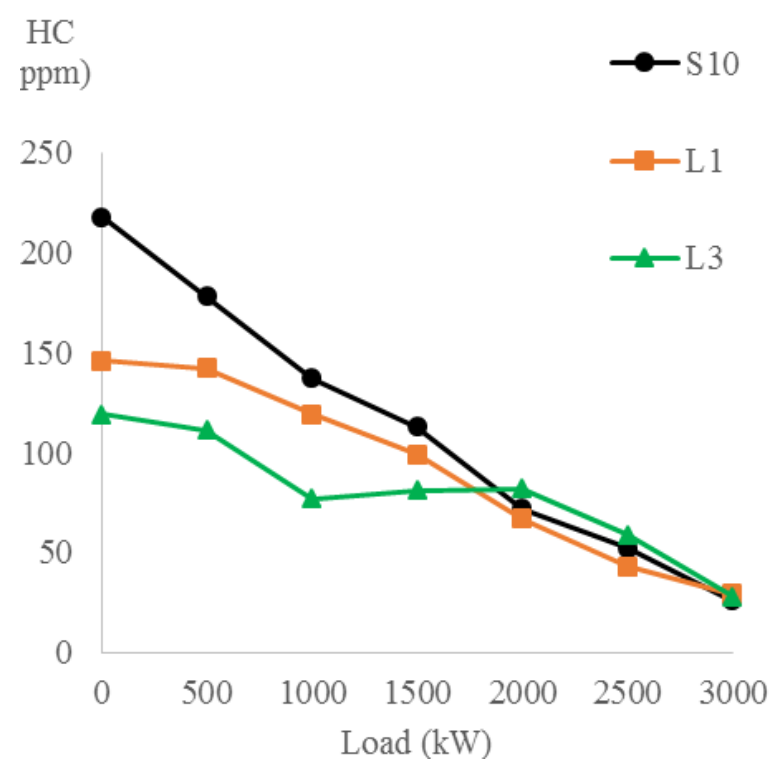

Figure 1. Unburned Hydrocarbons emissions.

The decrease in emissions of unburned $\mathrm{HC}$ is usually followed by an increase in $\mathrm{CO}_{2}$.

Figure 2 presents close values for the three compositions, especially in the range 1000 to $2000 \mathrm{~W}$.

For smaller loads, less than $1000 \mathrm{~W}$, the mixture L3 showed an increase in $\mathrm{CO}_{2}$ emissions while for loads above $2000 \mathrm{~W}$ there was a decrease.

The L1 mixture however presented an increase above $2000 \mathrm{~W}$.

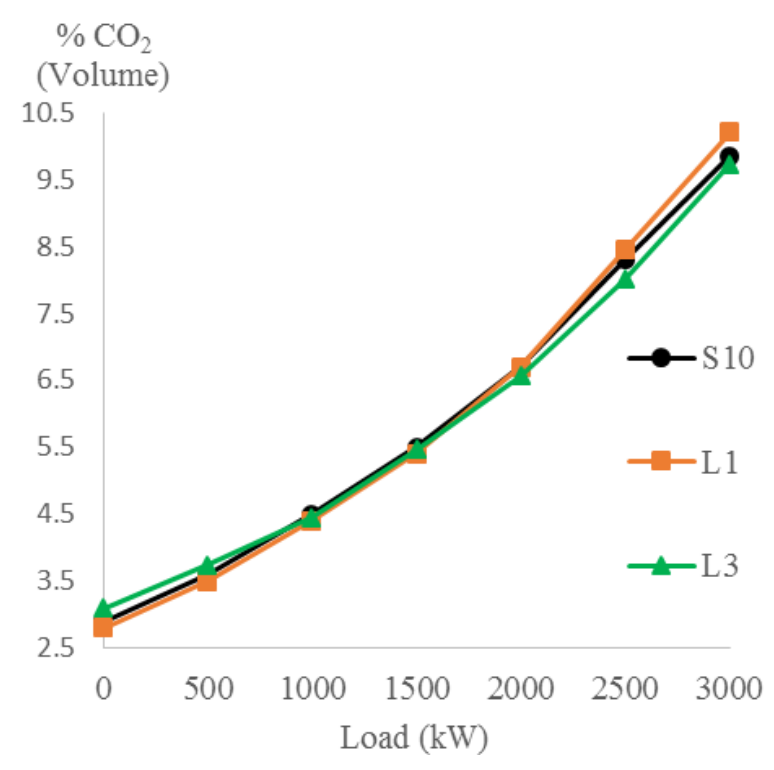

Figure 2. Carbon dioxide emissions.

With the decrease of $\mathrm{HC}$ and increase of $\mathrm{CO}_{2}$ when running the blend $\mathrm{L} 1$, it is expected that the emission of $\mathrm{CO}$ would be lower, which can be proved in Fig. 3.

The results obtained with the blend L1 are desirable, unlike those obtained with L3. 


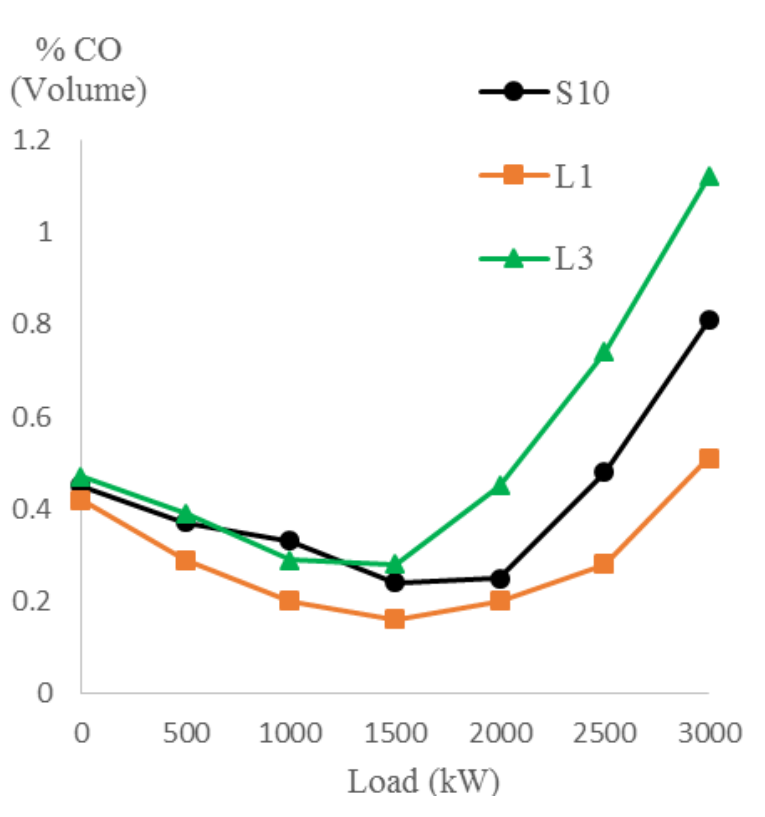

Figure 3. Carbon monoxide emissions.

The behavior of the mixture blend D+L3 was not expected mainly above $1500 \mathrm{~W}$ of load.

This change of pattern may be related to the change in the air-fuel ratio at high loads, the fuel spray shape, the combustion chamber geometry, and an higher oxidation tendency of the additive (dlimonene) than the fuel, preventing the oil from being completely consumed.

The emission values of $\mathrm{O}_{2}$ shown on Fig. 4 were very close, over the entire range of loads, not indicating significant differences.

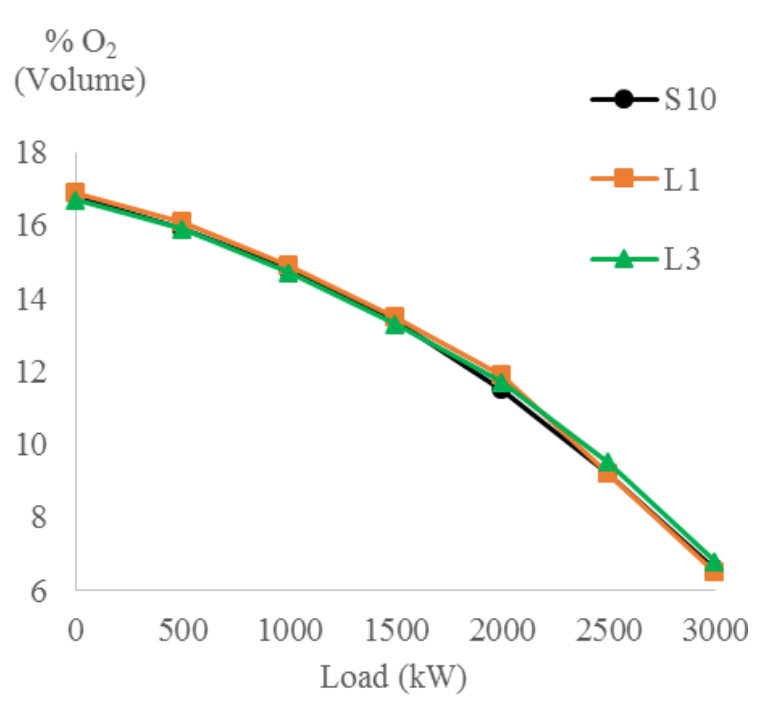

Figure 4. Oxygen emissions.

We can observe in Fig. 5 that the emissions of nitrogen oxides follow the same pattern with a point of divergence in $2000 \mathrm{~W}$ when running on L3 blend.

We can see from the graph that for loads of up to $2000 \mathrm{~W}$, the use of the additive increased $\mathrm{NO}_{\mathrm{x}}$ emissions, but at higher loads, it is possible to affirm that the additive did not change the emission levels.

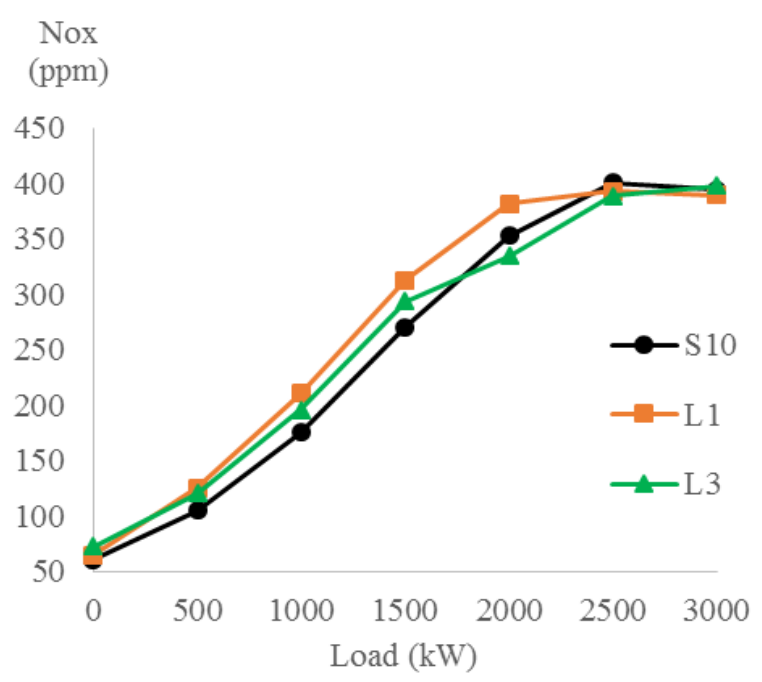

Figure 5. Nitrogen oxide emissions.

With respect to the opacity, we can see in Fig. 6 a great improvement with L1, and a marked variation with L3. Using the L3 blend at the load of $2000 \mathrm{~W}$ was expected a lower level of emissions of particulate matter.

This fact may be related to some error in the data acquisition and should be investigated.

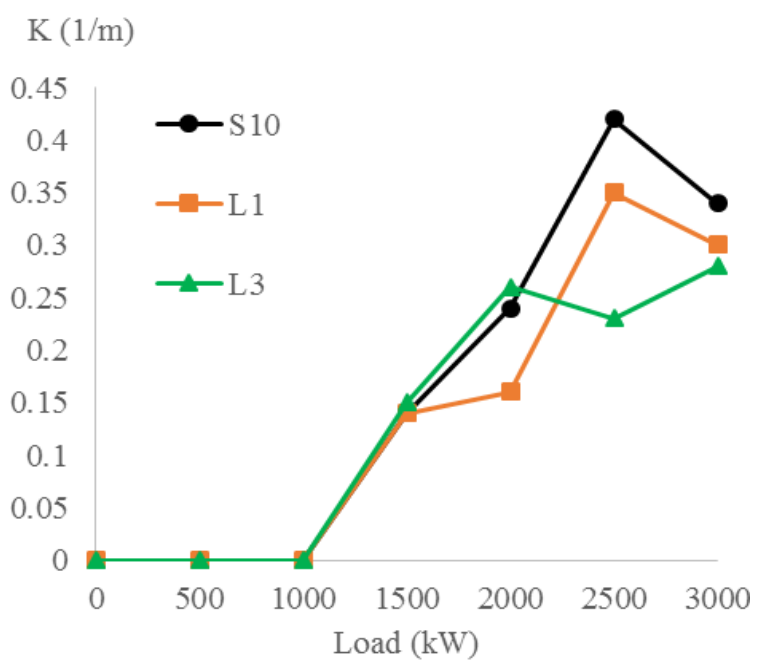

Figure 6. Opacity.

The temperature of the exhaust gas presented close results for the three samples, as observed in Fig. 7 , but the samples with additive presented a small decrease of the temperature until the load of $2000 \mathrm{~W}$.

A practically identical behavior could be observed in the specific consumption, Fig. 8, for the three blends. This fact shows that the use of the additive did not cause significant changes in the heat of combustion of the mixture. 


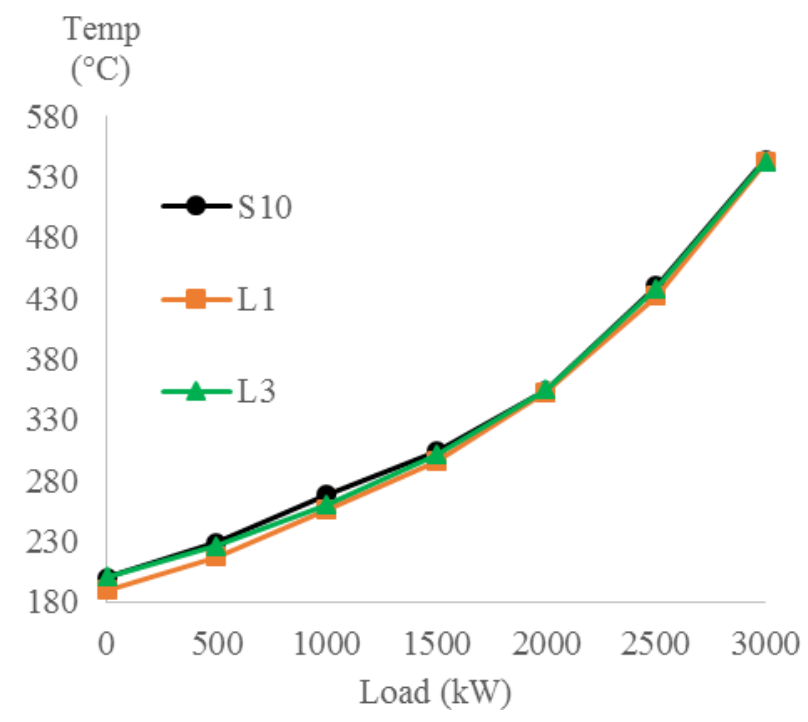

Figure 7. Exhaust gases temperature.

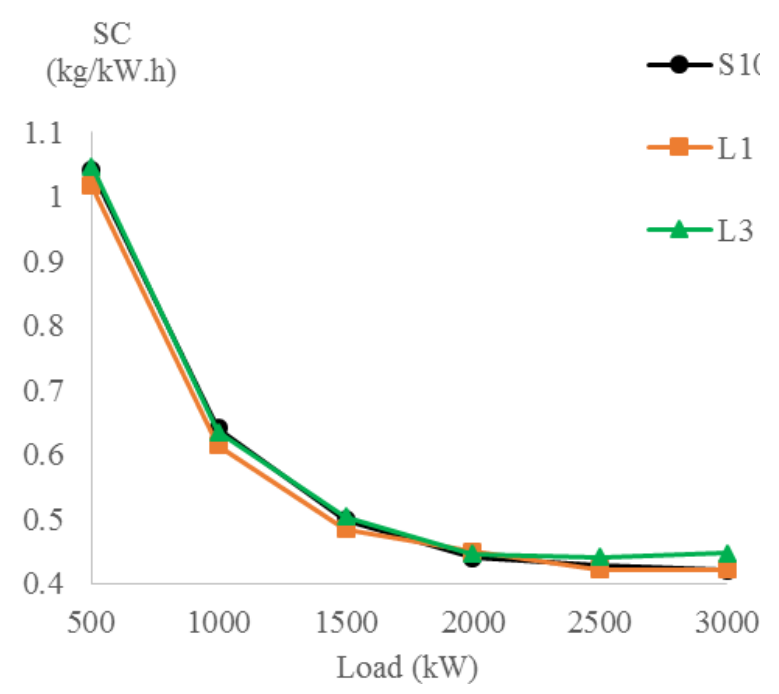

Figure 8. Specific consumption.

\section{CONCLUSIONS}

In the cases studied there were no problems related to the operation of the equipment.

Although obtaining some desired results such as decrease of $\mathrm{HC}, \mathrm{CO}$ and opacity, it is still necessary to test new compositions and seek better results, $\mathrm{NO}_{2}$ emissions is one of them.

New trials will be carried out seeking more conclusive results of the use of d-limonene and the better understanding of the obtained results and the unexpected ones such as the emission of $\mathrm{CO}$ using the blend L3.

\section{ACKNOWLEDGEMENTS}

The authors thank the "Fundação de Amparo à Pesquisa do Estado de São Paulo" - FAPESP, for funding this work through process number 2014/12107-7.

\section{REFERENCES}

Agarwal, A. K., and Das, L. M., 2001, Biodiesel Development Characterization for Use as a Fuel in Compression Ignition Engines, Transations of the ASME: Journal of Engineering for Gas Turbines and Power, Vol. 123, pp. 440-447.

Breitmaier, E., 2006, Terpenes, Wiley-VCH Verlag GmbH \& Co. KGaA

Clark, S. J., Wagner, L., Schrock, M. D., and Piennaar, P. G., 1984, Methyl and Ethyl Soybean Ester as Renewable Fuels for Diesel Engines, Journal of American Oil Chemistry Society, Vol. 61, No. 10, pp. 1632-1638.

Corazza, M. L., Rodrigues, D. G., and Nozaki, J., 2001, Preparação e Caracterização do Vinho de Laranja, Química Nova, Vol. 24, No. 4, pp. 449-452. (in Portuguese)

Costa Neto, P. R., and Rossi, L. F. S., 2000, Produção de Biocombustível Alternativo ao Óleo Diesel através da Transesterificação de Óleo de Soja Usado em Frituras, Química Nova, Vol. 23, No. 4, pp. 531-537. (in Portuguese)

Gaurav, P., Ambarish, D., and Bijan, K. M., 2014, An Experimental and Numerical Investigation of the Performance, Combustion and Emission Characteristics of a Diesel Engine Fueled with Jatropha Biodiesel, Energy Procedia, Vol. 54, pp. 455-467.

Gumus, M., 2010, A Comprehensive Experimental Investigation of Combustion and Heat Release Characteristics of a Biodiesel (Hazelnut Kernel Oil Methyl Ester) Fueled Direct Injection Compression Ignition Engine, Fuel, Vol. 89, pp. 2802-2814.

Hunk, A. L., and Barsic, N. J., 1981, Performance and Emission Characteristics of Naturally Aspirated Diesel Engine with Vegetable Oil Fuels - (Part 2), SAE paper, No. 810955.

Knothe, G., Gerpen, J. V., Krahl, J., and Ramos, L. P., 2006, Manual de Biodiesel, Edgard Blücher. (in Portuguese)

Lapuerta, M., Armas, O., and Fernandez, J. R., 2008, Effect of Biodiesel Fuels on Diesel Engine Emissions, Progress in Energy and Combustion Science, Vol. 34, pp. 198-223. 